\title{
Complementary and integrative care practices in symptom management in breast cancer patients
}

\author{
Seda Pehlivan ${ }^{1 *}$, Diğgdem Lafçı ${ }^{2}$ and Nursel Vatansever ${ }^{3}$ \\ ${ }^{1}$ Department of Internal Medicine Nursing, Health Sciences Faculty, Uludag University, Turkey \\ ${ }^{2}$ Department of Fundamentals Nursing, School of Health, Mersin University, Turkey \\ ${ }^{3}$ Department of Surgery Nursing, Health Sciences Faculty, Uludag University, Turkey
}

\begin{abstract}
Objective: The aim of this study is to discuss the results of complementary and integrative care practice in symptom management in patients with breast cancer in nursing postgraduate theses conducted in our country.

Materials and methods: In the study, among the postgraduate theses conducted in the field of nursing from the website of the National Thesis Center, 74 studies conducted on patients with breast cancer were reached by browsing with "breast" as the key word. A total of 15 postgraduate nursing studies having complementary and integrative care applications, including 5 master's theses and 10 doctoral theses, were examined. The year, thesis type and department of all the thesis were recorded.

Results: It was determined that 5 of the postgraduate nursing these studies related to complementary and integrative care practice were master's theses and 10 were doctoral theses. Symptoms of the study were determined to be pain, nausea / vomiting, fatigue, lymphedema, anxiety, depression, sleep and alopecia. Complementary and integrative maintenance applications were determined to be relaxation exercise, aromatherapy, lymph drainage massage, reflexology, scalp cooling, acupressure and ginger use. In the studies examined, complementary and integrative care practices were found to be effective in symptom management.

Conclusion: Postgraduate nursing thesis studies demonstrate the effectiveness of complementary and integrative care practices in symptom management in patients with breast cancer. The increased involvement of nursing care practices for symptom management will contribute to the development of evidence-based practices in
\end{abstract} this field.

\section{Introduction}

Among the health problems in the world and in our country, cancer is the second most common cause of death in developed countries after heart diseases [1]. As a result of the developments that take place in medicine, while there is a chance to treat some cancer cases, cancer has acquired a chronic course in others by extension of the length of life [2]. In this process, as much as the symptoms caused by the disease, patients also experience many physical and emotional problems such as pain, anorexia, cachexia, taste changes, alopecia, nausea, vomiting, dehydration, mucositis, xerostomia, fatigue, dyspnea, bone marrow depression, depression, anxiety etc. due to side effects of chemotherapy and radiotherapy [3].

It is known that patients use complementary and integrative care (CIC) practices along with medical treatments to cope with the symptoms of the disease, increase the quality of life and prolong the life span $[4,5]$. Recent studies indicate that on average $50 \%$ of cancer patients use CIC and that the number of patients using these treatments is increasing [6]. The usage of complementary and integrative treatment is higher in North America than in Europe. The usage of CIC in Europe is minimum in Italy and maximum in Denmark and Germany. In general CIC users are reported to be younger and educated and have a higher socioeconomic status [7].

There are many studies about the usage of CIC in our country. In the literature study conducted in our country, it is stated that the frequency of CIC use of cancer patients varies between $22.1 \%$ and
$84.1 \%$ [8]. It is reported that $41 \%$ of cancer patients in the east of our country and $42 \%$ of them in the west use CIC [9]. In a study conducted by Malak et al. [10], it was reported that $87.2 \%$ of cancer patients use CIC, and that $23.6 \%$ of these patients are breast cancer patients. It is also known that, in patients with breast cancer, unwanted physical and emotional symptoms due to disease process and treatments affect patients' quality of life negatively [11]. Postgraduate studies are being conducted by nurses to develop evidence-based practices in the management of symptoms. The aim of this study is to discuss the results of complementary and integrative care practice in symptom management in patients with breast cancer in nursing postgraduate thesis studies conducted in our country.

\section{Materials and methods}

In the study, among the postgraduate theses conducted in the field of nursing on the official web page of the National Thesis Center, 74 studies on patients with breast cancer were reached by browsing with the keyword "breast". It was determined that nursing theses related

Correspondence to: Seda Pehlivan, RN, PhD, Uludag University, Faculty of Health Sciences, Bursa, TR-16059, Turkey, Tel: 902242942462; Fax: 902242944251; E-mail: pehlivan_seda@hotmail.com

Key words: breast cancer, complementary and integrative care practices, nursing Received: April 06, 2017; Accepted: April 25, 2017; Published: April 28, 2017 
to breast cancer were done between $1998-2016$ and the maximum number of studies was in 2008. Of the studies, 45 were determined to be master's theses and 29 were determined to be doctorate theses. The theses were found to be mostly in the departments of surgical nursing, public health nursing and internal medicine nursing. A total of 15 nursing studies having complementary and integrative care practices, including 5 master's theses, were examined from these theses. The year of all theses, the type of thesis, the department, the number of samples, the symptom studied, the complementary and integrative care application and the result of the application were recorded.

\section{Results}

The departments in which nursing thesis studies that use complementary and integrative care practices are used were determined to be internal medicine nursing, surgical diseases nursing, psychiatric nursing and nursing principles respectively (Table 1 ). The most commonly studied symptoms were determined to be anxiety/ depression, quality of life, nausea/vomiting, fatigue, lymphedema respectively. Complementary and integrative care practices were determined to be relaxation exercise, aromatherapy, lymph drainage massage, reflexology, scalp cooling, acupressure and ginger use.

\section{Discussion}

The purposes of cancer treatment are reduction/control of symptoms and a better quality of life for the patient [12]. In a study conducted by Hwang et al. [13], the rate of CIC use in patients with breast cancer was $67 \%$ while the reasons for use were determined as stopping the progression of the disease (39.4\%) and relieving the symptoms (32.1\%). As it can be understood from the results of this research, the reasons for using CIC methods of patients and the targets of medical treatment are the same. When patients do not reach the expected treatment goals, they begin to look for alternative methods. In a study conducted in patients with breast cancer undergoing chemotherapy, it was determined that $87 \%$ of the patients were using CIC; these practices were patient-applied practices such as dietary supplements $(70 \%)$, vitamin and mineral supplements $(36 \%)$, herbal products $(42 \%)$, other natural products $(41 \%)$, mind-body based applications (71\%), yoga and meditation (24\%) and specialist applications such as massage, acupuncture and reiki [14]. When the high usage rate and the distribution of the methods used is considered; it is seen that patients apply methods that may not be safe (such as herbal products) after deciding on their own. It is believed that health professionals' work on CIC methods' effectiveness is very important. Only as a result of these studies, it will be possible for patients to be informed about the use of safe and effective methods.

Nurses are working on an increasing number of complementary and integrative care practices for symptom management. In the study that they have done, Witt and Cardoso (2016) reviewed the results of studies investigating the effectiveness of complementary and integrative care practices in patients with breast cancer. Symptoms in the studies were determined as nausea/vomiting, pain, fatigue, anxiety, depressive symptoms, sleep disturbance and quality of life. The complementary and integrative care practices used were determined as acupuncture, acupressure, hypnosis, meditation, relaxation, yoga, music therapy, massage and use of ginger. In symptom management; it has been shown that the strongest evidence is in applying yoga, hypnosis, meditation, relaxation [15]. It is seen that the symptoms studied in our country are similar, but there are some differences in complementary and integrative care practices applied. The fact that mind-body based practices with strong evidence are never used in our

Table 1. Postgraduate theses with complementary and integrative care practices in symptom management of patients with breast cancer.

\begin{tabular}{|c|c|c|c|c|c|}
\hline Author & Department / Thesis type & Sample & Practices & Symptom & Results \\
\hline $\begin{array}{l}\text { Türk G. } \\
2002\end{array}$ & $\begin{array}{l}\text { Surgical Nursing } \\
\text { Master's }\end{array}$ & $\begin{array}{l}28 \text { patient } \\
\text { mastectomy }\end{array}$ & Arm exercises & Lymphedema & Positive effect \\
\hline $\begin{array}{l}\text { Taş Gül A. } \\
2005\end{array}$ & $\begin{array}{l}\text { Surgical Nursing } \\
\text { Doctorate }\end{array}$ & 2 groups -64 patient & Aromatik lenf drenajı masajı & Lymphedema & Positive effect \\
\hline $\begin{array}{l}\text { Demiralp M. } \\
\quad 2006\end{array}$ & $\begin{array}{l}\text { Psychiatry Nursing } \\
\text { Doctorate }\end{array}$ & $\begin{array}{c}27 \text { patient } \\
\text { Self-controlled }\end{array}$ & Relaxation training & $\begin{array}{c}\text { Anxiety, depression, sleep quality, } \\
\text { fatigue }\end{array}$ & Positive effect \\
\hline $\begin{array}{l}\text { Lafçı D. } \\
2009\end{array}$ & $\begin{array}{c}\text { Fundamentals Nursing } \\
\text { Master's }\end{array}$ & 2 groups -60 patient & Music & Sleep quality & Positive effect \\
\hline $\begin{array}{l}\text { Ucuzal M. } \\
2009\end{array}$ & $\begin{array}{l}\text { Surgical Nursing } \\
\text { Doctorate }\end{array}$ & $\begin{array}{l}2 \text { groups }-70 \text { patient } \\
\text { mastectomy }\end{array}$ & Foot massage & Pain & Positive effect \\
\hline $\begin{array}{l}\text { Genç F. } \\
2010\end{array}$ & $\begin{array}{l}\text { Internal Medicine Nursing } \\
\text { Doctorate }\end{array}$ & 2 groups -64 patient & Acupressure & Nausea, vomiting and anxiety & Positive effect \\
\hline $\begin{array}{l}\text { Ovayolu Ö. } \\
2011\end{array}$ & $\begin{array}{l}\text { Internal Medicine Nursing } \\
\text { Doctorate }\end{array}$ & $\begin{array}{l}4 \text { groups - } 280 \text { patient } \\
\text { chemotherapy }\end{array}$ & Aromatherapy & $\begin{array}{l}\text { Symptoms } \\
\text { Quality of life }\end{array}$ & Positive effect \\
\hline $\begin{array}{l}\text { Arıkan Dönmez A. } \\
2012\end{array}$ & $\begin{array}{c}\text { Fundamentals Nursing } \\
\text { Master's }\end{array}$ & $\begin{array}{l}2 \text { groups }-50 \text { patient } \\
\text { chemotherapy }\end{array}$ & Scalp cooling & Alopesi & Positive effect \\
\hline $\begin{array}{l}\text { Doğan S. } \\
2012\end{array}$ & $\begin{array}{l}\text { Psychiatry Nursing } \\
\text { Doctorate }\end{array}$ & 2 groups -70 patient & Relaxation exercise & Fatigue, depression, quality of life & Positive effect \\
\hline $\begin{array}{l}\text { Özdelikara A. } \\
2013\end{array}$ & $\begin{array}{l}\text { Internal Medicine Nursing } \\
\text { Doctorate }\end{array}$ & $\begin{array}{l}2 \text { groups }-60 \text { patient } \\
\text { chemotherapy }\end{array}$ & Reflexology & Fatigue, nausea, vomiting & Positive effect \\
\hline $\begin{array}{l}\text { GürdilYilmaz S. } \\
2014\end{array}$ & $\begin{array}{l}\text { Surgical Nursing } \\
\text { Master's }\end{array}$ & $\begin{array}{l}2 \text { groups }-60 \text { patient } \\
\text { mastectomy }\end{array}$ & Progressive relaxing exercises & Anxiety, comfort & Positive effect \\
\hline $\begin{array}{l}\text { Şengün İnan F. } \\
2014\end{array}$ & Psychiatry Nursing Doctorate & $\begin{array}{c}32 \text { patient } \\
\text { Self-controlled }\end{array}$ & Psychoeducation & $\begin{array}{l}\text { Distress, anxiety, depression, } \\
\text { quality of life }\end{array}$ & Positive effect \\
\hline $\begin{array}{c}\text { Arslan M. } \\
2014\end{array}$ & $\begin{array}{l}\text { Internal Medicine Nursing } \\
\text { Doctorate }\end{array}$ & $\begin{array}{l}2 \text { groups }-60 \text { patient } \\
\text { chemotherapy }\end{array}$ & Ginger & Nausea-vomiting, retching & Positive effect \\
\hline $\begin{array}{c}\text { Nemli P.A. } \\
2015\end{array}$ & $\begin{array}{l}\text { Internal Medicine Nursing } \\
\text { Master's }\end{array}$ & $\begin{array}{c}2 \text { groups }-62 \text { patient } \\
\text { mastectomy }\end{array}$ & Exercise & Physcial activity, quality of life & Positive effect \\
\hline $\begin{array}{l}\text { Arıkan Dönmez A. } \\
2016\end{array}$ & $\begin{array}{l}\text { Internal Medicine Nursing } \\
\text { Doctorate }\end{array}$ & 2 groups - 52 patient & $\begin{array}{l}\text { Physcial activity programme and } \\
\text { simple lymphatic drainage massage }\end{array}$ & Lymphedema & Positive effect \\
\hline
\end{tabular}


country can be explained by the lack of educated practitioners in this respect. Moreover, the fact that it is not culturally applicable and the lack of awareness of these practices by our society can be listed among reasons as to why it is not applied.

Studies have shown that exercise reduces fatigue which is among the most common symptoms in cancer patients and increases quality of life [16]. In a study that they have done, Schmidt et al. found that, after giving exercise training and 12 weeks of group training to patients with breast cancer, there was a positive change in the fatigue, quality of life, depression, cognitive capacity, muscle strength and inflammatory parameters of the patients [17]. In her thesis study, Nemli found that regular exercise and follow-up in patients with breast cancer who had undergone mastectomy increased the level of physical activity and quality of life of patients [18]. In two different thesis studies investigating the effect of relaxation exercises in patients with breast cancer receiving chemotherapy, it has been determined that it has a curative effect on sleep quality, fatigue and depression $[19,20]$. In another thesis study, it has been shown that progressive relaxation exercises have a positive effect on anxiety and comfort levels in patients with breast cancer who had undergone mastectomy [21-25]. In patients with breast cancer, exercise can be said to be an effective complementary and integrative care practice for controlling symptoms such as fatigue and depression.

Chemotherapy-induced nausea/vomiting is considered the most common, unpleasant, and worrying side effect [26]. Chemotherapyinduced nausea/vomiting has been reported in $55-94 \%$ of breast cancer patients [27]. In three different thesis studies, acupressure [28] reflexology [29] and ginger use [30] applied in patients with breast cancer have been shown to reduce chemotherapy-induced nausea/ vomiting. Control of this symptom, which is commonly encountered during chemotherapy and adversely affects the treatment process of the patient, is thought to be very important.

Lymphedema is one of the most troublesome complications that occur in about $24 \%$ of patients after mastectomy. Decongestive lymphatic therapy (DLT) with skin care, manual lymphatic drainage (MLD), exercise and compression therapy (with a multilayer bandage or garment) is widely used and considered the best practice in lymph therapy management [22]. Stone found that aromatic lymph drainage massage and simple lymph drainage massage prevented the development of lymphedema in his thesis study with 64 patients who underwent mastectomy [23]. Türk [24] in her study showed that arm exercises and Arıkan-Dönmez [25] showed that early-phase physical activity and simple lymph drainage massage were effective in preventing lymphedema after breast cancer surgery. It is thought that, in prevention of lymphedema, it is necessary to give information to the nurses that provide care to the patients with mastectomy about arm exercise, early physical activity, and simple lymph drainage massage.

Other symptoms that may occur due to chemotherapy and cancer treatments in patients with breast cancer include pain, sleep disturbance, anorexia, anxiety, depression, constipation/diarrhea, hair loss, etc. [26]. Studies have indicated that reflexology is an effective treatment for the control of side effects of pain, anxiety, depression and chemotherapy in cancer patients [31]. In the thesis study investigating the effect of aromatherapy massage [32] applied to patients with breast cancer receiving chemotherapy treatment, it has been shown to have a positive effect on symptoms and quality of life. in his thesis study, Şengün İnan found that psychoeducation applied to patients with breast cancer reduced distress, anxiety, depression and improved quality of life [33]. Ucuzal reported that foot massage applied after breast surgery reduced post-operative pain in patients with breast cancer [34]. In the thesis study conducted with patients with breast cancer who are hospitalized, it has been found that music improved sleep quality and increased satisfaction [35]. In the Arıkan Dönmez thesis study, it was found that cooling applied to the scalp reduced the hair loss [36]. It is thought that in patients with breast cancer, more randomized controlled trials are needed in large populations where complementary and integrative care practices can be implemented by nurses.

\section{Conclusion}

Postgraduate nursing thesis studies show that complementary and integrative care practices are effective in symptom management of patients with breast cancer. The increase in randomized controlled trials involving nursing care practices for symptom management will contribute to the development of evidence-based practices in this field. It is also thought that it is important to give information on this subject to the nurses who give care to patients with breast cancer so that the results of the study can be reflected to practice.

\section{References}

1. Aslan Ö, Vural H, Kömürcü S, Özet A (2006) Kemoterapi alan kanser hastalarina verilen egitimin kemoterapi semptomlarina etkisi. C.Ü. Hemsirelik Yüksekokulu Dergisi 10: 15-28.

2. Aydogan F, Uygun K (2011) Kanser Hastalarinda Palyatif Tedaviler. Klinik Gelisim 24: 4-9.

3. Ünsar S, Yildiz Findik Ü, Kurt S, Özcan H (2007) Kanserli hastalarda evde bakim ve semptom kontrolü. Firat Saglik Hizmetleri Dergisi 2: 89-106.

4. Lee MM, Lin SS, Wrensch MR, Adler SR, Eisenberg D (2000) Alternative therapies used by women with breast cancer in four ethnic populations. J Natl Cancer Inst 92: 42-47. [Crossref]

5. Chang EY, Glissmeyer M, Tonnes S, Hudson T, Johnson N (2006) Outcomes of breast cancer in patients who use alternative therapies as primary treatment. Am J Surg 192: 471-473. [Crossref]

6. Horneber M, Bueschel G, Dennert G, Less D, Ritter E, et al. (2012) How many cancer patients use complementary and alternative medicine: a systematic review and metaanalysis. Integr Cancer Ther 11: 187-203. [Crossref]

7. Cassileth BR, Deng G (2004) Complementary and alternative therapies for cancer Oncologist 9: 80-89. [Crossref]

8. Kav S, Hanoglu Z, Algier L (2008) Türkiye'de kanserli hastalarda tamamlayici ve alternatif tedavi yöntemlerinin kullanimi: Literatür taramasi. Uluslararasi HematolojiOnkoloji Dergisi 1: 32-38.

9. Gozum S, Tezel A, Koc M (2003) Complementary alternative treatments used by patients with cancer in eastern Turkey. J Clin Res Pediatr Endocrinol 26: 230-236. [Crossref]

10. Malak AT, Karayurt O, Demir E, Yümer AS (2009) Complementary and alternative medicine in cancer patients - analysis of influencing factors in Turkey. Asian Pac J Cancer Prev. 10: 1083-1087.

11. Salonen P, Kellokumpu-Lehtinen PL, Tarkka MT, Koivisto AM, Kaunonen M (2011) Changes in quality of life in patients with breast cancer. J Clin Nurs 20: 255-266. [Crossref]

12. Foxson SB, Lattimer JG, Felder B (2011) Breast Cancer. In: Cancer Nursing Principles and Practice. Yarbro $\mathrm{CH}$, Wujcik D, Gobel BH eds. ( $7^{\text {th }}$ Edn). Jones and Bartlett Publishers, USA: 1091-1145.

13. Hwang JH, Kim WY, Ahmed M, Choi S, Kim J, et al. (2015) The Use of Complementary and Alternative Medicine by Korean Breast Cancer Women: Is It Associated with Severity of Symptoms? Evid Based Complement Alternat Med 2015: 182475. [Crossref]

14. Greenlee H, Sardo Molmenti CL, Falci L, Ulmer R, Deming-Halverson S, et al. (2016) High use of complementary and alternative medicine among a large cohort of women with a family history of breast cancer: The Sister Study. Breast Cancer Res Treat 156: 527-538. [Crossref]

15. Witt CM, Cardoso MJ (2016) Complementary and integrative medicine for breas cancer patients-Evidence based practical recommendations. Breast 28: 37-44. [Crossref] 
16. Lipsett A, Barrett S, Haruna F, Mustian K, O’Donovan A (2017) The impact of exercise during adjuvant radiotherapy for breast cancer on fatigue and quality of life: A systematic review and meta-analysis. Breast 32: 144-155. [Crossref]

17. Schmidt ME, Wiskemann J, Krakowski-Roosen H, Knicker AJ, Habermann N, et al. (2013) Progressive resistance versus relaxation training for breast cancer patients during adjuvant chemotherapy: design and rationale of a randomized controlled trial (BEATE study). Contemp Clin Trials 34: 117-25. [Crossref]

18. Nemli PA (2015) Meme kanserli kadinlarda mastektomi sonrasi düzenli egzersiz ve izlemlerin fiziksel aktivite ve yasam kalitesine etkisi.

19. Dogan S (2012) Gevseme egzersizinin adjuvan kemoterapi alan meme ve kolorektal kanser tanili hastalarin yorgunluk, depresyon ve yasam kalitesi düzeyine etkisi.

20. Demiralp M (2006) Gevseme egitiminin, adjuvan kemoterapi uygulanan meme kanserli hastalarda anksiyete ve depresyon belirtileri, uyku kalitesi ve yorgunluk üzerine etkisi.

21. Gürdil Yilmaz S (2014) Mastektomi ameliyati geçiren hastalarda progresif gevseme egzersizlerinin anksiyete ve konfor üzerine etkisi.

22. Bozkurt M, Palmer LJ, Guo Y (2017) Effectiveness of decongestive lymphatic therapy in patients with lymphedema resulting from breast cancer treatment regardless of previous lymphedema treatment. Breast $J$ 23: 154-158. [Crossref]

23. Gül (Tas) A (2005) Meme kanseri ameliyatlarindan sonra lenfödemin önlenmesinde basit lenf drenaji masaji ilearomatik yaglarla yapilan basit lenf drenaji masajinin etkisinin karsilastirilmasi.

24. Türk G (2002) Mastektomi sonrasi yaptirilan kol egzersizlerinin lenfödemi önlemeye etkisi.

25. Arikan Dönmez A (2016) Meme kanseri iliskili lenfödemin önlenmesinde fiziksel aktivite programi ve basit lenfatik drenaj masajinin etkinligi.
26. Chee Chean D, Kuo Zang W, Lim M, Zulkefle N (2016) Health Related Quality of Life (HRQoL) among Breast Cancer Patients Receiving Chemotherapy in Hospital Melaka: Single Centre Experience. Asian Pac J Cancer Prev 17: 6021-6026.

27. Peoples AR, Roscoe JA, Block RC, Heckler CE, Ryan JL, et al. (2017) Nausea and disturbed sleep as predictors of cancer-related fatigue in breast cancer patients: a multicenter NCORP study. Support Care Cancer 25: 1271-1278.

28. Genç F (2010) Meme kanserli hastalarda akupresür uygulamasinin kemoterapiye bagli bulanti kusma ve anksiyete üzerine etkisi.

29. Özdelikara A (2013) Meme kanserli hastalarda refleksolojinin kemoterapiye bagl bulanti, kusma ve yorgunluk üzerine etkisi.

30. Arslan M (2014) Meme kanserli kadin hastalarda kemoterapiye bagli gelisen bulanti, kusma ve ögürme üzerine zencefil kullaniminin etkisi.

31. Kim JI, Lee MS, Kang JW, Choi DY, Ernst E (2010) Reflexology for the symptomatic treatment of breast cancer: a systematic review. Integr Cancer Ther 9: 326-330. [Crossref]

32. Ovayolu Ö (2011) Kemoterapi alan meme kanserli kadinlara uygulanan aromaterapinin semptomlara ve yasam kalitesi etkisi.

33. Sengün Inan F (2014) Meme kanseri hastalarina tedavi sonrasinda evde yapilan psikoegitimin distres, anksiyete, depresyon ve yasam kalitesine etkisi.

34. Ucuzal M (2009) Meme ameliyati olan hastalarda ayak masajinin ameliyat sonrasi agriya etkisi.

35. Lafçi D (2009) Müzigin kanser hastalarinin uyku kalitesi üzerine etkisi.

36. Arikan Dönmez A (2012) Meme kanseri olan hastalarda scalp cooling (saçli deriyi sogutma) yönteminin kemoterapiye bagli saç kaybi üzerine etkisi.

Copyright: (2017 Pehlivan S. This is an open-access article distributed under the terms of the Creative Commons Attribution License, which permits unrestricted use, distribution, and reproduction in any medium, provided the original author and source are credited. 